\title{
Place-making, Politics and Borderscapes in Southeastern Europe
}

\author{
Davide N. Carnevale \\ University of Padova \\ Thomas M. Wilson \\ Binghamton University; State University of New York
}

\begin{abstract}
This article introduces a collection of case studies on the politics of borders and the place-making processes in Southeast European border environments. It opens with explorations of how the social analysis of borders oscillates between border studies and border theory, and between the study of borders as things and as ideas. The focus on the territoriality of borders, analyzed as dynamic social-spatial formations, is proposed as a meeting point between the two approaches. On this premise, this article examines some key elements in contemporary ethnographic research on borders in Southeastern Europe.
\end{abstract}

The anthropology of borders is inextricably tied to ethnographic research in borderlands and among border peoples, who live, or work, or play, or travel through border areas, and many of whom do all of these. It has roots in the earliest days of the discipline - dating to various interests in cultural diffusion, ethnic boundaries, and history - and it was most recently revitalized in the 1990s, in challenging but exciting times. Among other changes, the Cold War had ended, many new states and their borders were created, there were promises of peace where border disputes had long threatened continued violence, and the benefits and problems of globalization had fostered new scholarly interest in borders that for some were disappearing and for others were just being transformed. Over the last decades, this anthropological interest in international and other geopolitical borders has gained momentum due to the apparent continuing vitality of international borders as sites and agents of state control, as demonstrated in the unpredicted and unprecedented numbers of economic and political migrants on the move from South to North and East to West worldwide. Thus, it is not surprising that the anthropology of borders, which has been largely framed by the longstanding and influential scholarship on the Mexico-US border, is now matched in volume and impact by scholarly studies of borders in, around, and beyond the European Union (EU).

A key theme in anthropological studies of these borderlands and border arrangements has been the examination of the many ways that institutional borders - the geopolitical ones, 
recognized in laws and treaties that seemingly mark the territorial and political extent of state sovereignty and national security - are also defined, approached and negotiated in their roles as social and cultural boundaries (Donnan and Wilson 1999). This anthropological attention to the border as structure and the border as symbolic demarcation has been couched in terms that associate the former with 'border studies' and the latter with 'border theory'. We will start to draw on this duality using two ethnographic anecdotes by Davide Carnevale.

\section{Achilles, the wheeled tortoise}

In September 2018, a few days after the end of a brief research in the trilateral border region of Prespa lakes, I was on the other shore of the Adriatic sea, in the region of the Italian peninsula which protrudes the most towards the Balkans. I had reached a village near Bari, which hosts a wildlife rescue center. I was carrying a young tortoise, which I had come across along a country road while it was slowly dragging its shell and paw, severely damaged by the tyre of a car. Showing great endurance, the small tortoise, initially on the verge of death, had got in few days its energies, appetite and speed back, but not its ideal gait. My first-aid intervention - a paper-taped carapace - had been useful, but not enough for Achilles - thus had the tortoise been christened - to have a full recovery.

At the rescue center, when she heard the word 'tortoise', the vet immediately went into a tirade about people who take tortoises from their habitat, detaining them illegally as pets on their balconies and home gardens. Examining Achilles, she said they would try to restore the use of its unmoving paw, but if the operation was not successful another minor surgery would allow Achilles to grow up on wheels. Dismissing me, the veterinarian clarified that, as required by law, Achilles would be returned to the wild, but 'obviously only in the case of an Italian turtle'. The vet assured me that the tortoise would, indeed, undergo a genetic test to ensure it was a local one. I discovered there are many smugglers who gather land tortoises throughout the rural areas of the Western Balkans - especially of the subspecies Testudo hermanni boettgeri, and various subspecies of Testudo graeca. They transport them illegally to resell them in Italy, where, as the doctor says, the 'black market of Albanian tortoises is always flourishing'. Illegally released or escaped from captivity, these 'foreign turtles' - in addition to the damage to the territories of origin - are feared for their impact on native species, already at risk due to the increasing shrinking of the rural landscape of the Italian peninsula. In order to avoid inter-species competition, genetic pollution and transmission of pathogens, the center has its own special section that shelters non-native turtles, while they wait for the chance to cross the Adriatic Sea again.

I was a little thrown by the idea that Achilles could be prosecuted as a potential illegal tortoise, left to the judgment of this atypical border agent, the veterinary. Devoted mainly to medical treatments and environmental safeguarding, she was in fact a representative of national sovereignty. Achilles was probably little aware of international treaties, state demarcations, and national identities, but the political relevance of this demarcation, with its agentic power, remained present nonetheless. 
Despite the arbitrariness and virtuality of any political divisions, social representations, and symbolic demarcations, on which so much ethnography has rightly focused, the border appeared in all its concreteness and importance, as a kind of givenness. Was the veterinary not an agent of the Washington CITES Convention, and an instrument of the governmental biopolitics of tortoises? How relevant might frontiers be to the life of a young wheeled tortoise?

\section{The twisted belly borderscape}

This same Southern-Italian region is characterized by karstic geology and little rain, yielding a rural landscape that appears burnt throughout the hot season, and rich in small ravines, sinkholes, aquifers and caves. Several furrows cross the ground of the whole area, mostly facing the coast. Not far from where the above-mentioned center is located today, one of these furrows splits a township into two villages, documented since the Middle Ages, and still connected by a single bridge. They were administratively reunified a century ago under the name of Adelfia, a benevolent Grecism meant to obliterate centuries of parochial disputes. Still today Adelfia is the only small municipality in the area to have two elementary schools, two post offices, and two cemeteries, one on each side of the gully, as well as two different patron saints and two dialects - plus a third, shared among the women of both districts.

About a century ago, an imposing water system, the Apulian Aqueduct, was built, putting an end to the shortage of surface water that had so decisively influenced the socio-economic morphology and history of the area, and allowing greater industrialization of the agricultural sector and urbanization. Among the canal and pipeline laborers were my great-grandfather and, occasionally, my grandfather as a boy. They worked in the countryside near the town of Acquaviva, where the company had long been building the pipelines that connected the main conduit to the neighboring towns. There, too, lie small dips and crevices, although the landscape appears rather uniform due to sprawling fields of olive trees, vineyards and almond groves.

The nearest village to Acquaviva is about 2.5 miles away travelling along a country road. My grandfather maintained that they spoke a terrible dialect in this other village, and he humorously suggested me not to look for a wife there, because it was a well-known fact that the local women had $u v^{\prime}$ ddiche t'rciute: a twisted belly. ${ }^{2}$ It is now beyond my ability to determine the origin of this stereotype. I often thought to research the manual skills of the midwife of the village at that time, probably left-handed and a bit clumsy. My grandfather's advice marked a boundary that is utterly rarefied and irrelevant for me today, but was well traced in his experience. He recognized and projected a meaningful demarcation between these two small towns, while his grandson sees no or little boundary and otherness, for what amounts to an almost indistinct part - politically, socially, geographically, linguistically - of the same agricultural southern area bordering the big city on the coast.

Where I could see nothing but a suburban environment, my grandpa had charted and crossed a borderscape. 


\section{Space to cross, place to stay}

Geopolitical borders have increasingly attracted anthropological interest due to the roles borders play in all manner of issues related to transnational, national and regional politics, economics, social welfare, social justice, migration, refugees, smuggling, and many other formal and informal aspects that mark the changing nature of nation, state, and region in Europe. The scholarship on borders over the last decades also grew in the former regimes in Central and Eastern Europe, where new crucial issues about national borders arose rather suddenly. Since the 1990s, anthropologists and ethnographers have recognized and embraced the need for studies of regional borders and their roles in the everyday lives of border peoples, both as physical apparatuses of the state and as social facts and cultural imaginaries. Other evidence of the vitality of anthropological investigations of the changing nature of local, regional and national borders in the Eastern reaches of Europe has been the rise of regular conferences and schools committed to the training in ethnographic approaches to borders, as has occurred annually in the Konitsa Summer School since 2006. This special issue of the Anthropology of East Europe Review is in large part a result of these initiatives.

The contributors to this issue show in various ways how ethnographic research in borderlands cannot elide perspectives on the border as a varying material space through the exploration of the border's lived dimensions and its facets of everyday life. Intensive research at international borders - that have received the most attention from scholars, policy-makers, and social critics of all sorts since the arrival of the national states - has shown quite persuasively that the two dimensions in studying borders, which we have introduced anecdotally, require equal levels of epistemological attention and empirical investigation. Metaphorical perspectives on boundaries as they are perceived and constructed, which treat the border as a device of definition and identification of the self and of social groups, cannot encompass all the dimensions of the existence of boundaries as things, as objects that concretely regulate the movements of goods, power, ideas, capital, people, and non-human organisms. At the same time, the opposite is also true: spatial delimitations exist as social and cultural configurations of spaces as much as they function as governmental and static entities. Furthermore, borders exist as a mode of politics depending on how different, potentially divergent and contested practices and representations impact social patterns for bounding. With and because of their tangibility, borders are tied to symbolic definitions of order, belonging and memory.

In fact, the anthropology of borders, and all other border studies across anthropology's cognate disciplines, show how the processes of bordering, by local, regional, national and international actors, make what borders are and what borders do extremely dynamic (see, for example, Paasi 1998; van Houtum et al. 2005; Reeves 2011; Scott et al. 2018). In borderlands, cultural, economic, political and social boundaries can coincide, overlap, traverse and even subvert each other. In other words, the border is above all a place, a "distinct space where people live; it encompasses both the idea and the actuality of where things are" (Donnan and Wilson 1999, 9). Consequently, it is widely held that the study of borders needs to combine, practically in terms of research design, and conceptually in terms of contributions to knowledge and theory, approaches to territorially-based political formations, often demarcated in laws, 
with the many aspects of the social construction of borderlands, where demarcations gained function and significance.

One of the crucial points in the anthropological approach to borders is thus the focus on territory, in the attempt to marry analyses of borders as objects, as subjects and as ideas. The research proposal put forward within this special issue stresses this focus, and precisely the focus on border territory as borderscape, meaning a space whose processes of socialization create configurations and features for the making of border as a place, through geographical, political, institutional and infrastructural profiles limiting and regulating material and symbolical fluxes.

The search for meeting points between objectivity and subjectivation of the border is not new, nor is it the sole domain of anthropologists and ethnographers. Numerous studies have aimed to explore how multiple borders and boundaries criss-cross all geopolitical territorial demarcations. Thus, it is not surprising that the development of scholarship on borders, which has enjoyed a remarkable proliferation over the past three decades, has on several occasions revealed a fascination with the intersections of 'border theory' and 'border studies' (Wilson and Donnan 2012). However, its accomplishments in an ethnographic project remain challenging, often because of those criss-crosses, and the multiple interpretations of what the borders are, where they are located, how they work, and how to live with them. Despite the evidence that emanates from borderlands about the border multiplicities (Andersen et al. 2012), some critics might see that the gap between the study of borders as things and that of borders as ideas seems to have gradually widened rather than narrowed. ${ }^{3}$

\section{Border as institutional fact and political device}

A first broad approach to borders has focused primarily on their political dimension and the main political phenomena associated with borders and borderlands. Ethnographic observation and anthropological analysis of borders have explored major changes in the forms of sovereignties, citizenships and social belonging since the fall of the Iron Curtain, changes that have called into question the neoliberal, counter-empirical, rhetoric of a borderless world. Great repercussions on the functions and management of borders also affected the institutional realizations of international, state, and regional governance. Border studies have engaged in the interdisciplinary analysis of the border as a political object, while dealing with the removal, strengthening, and transformation of borders as they intersect with other forms of political

authority. For example, the topic has been approached by looking at the growing importance of cross-border governmental bodies, of transnational organizations, and of non-governmental actors and lobbies (Bucken-Knapp and Schack 2001). Starting from the fractures between ethnicity, nation and statehood, researchers of borderlands have dwelled on the new pressures of national assimilation and on renovated state-centristic logics (Donnan and Wilson 1998, 1999). Anthropological studies, among many others, have also extensively explored the effects on state boundaries of the mondialization of market economies (Heyman 2017), the intersection of humanitarian and environmental crises with border regulations and deregulations (Paasi et al. 2019), the penetrations and exacerbations of security issues in the narratives of borders and mobility (Cabot 2014), with borderlands designed by the proliferation of new walls (Brown 
2010; Tsoni and Frank 2019), as well as by new technologies for control, which still can also deal death and destruction (Cunningham 2020; Israel 2020).

Political analyses of borders have also dealt with what many have seen as the increasing ineffectiveness of twentieth-century state apparatuses. With equal visibility, the last decades of the de-democratization of the public sphere seemed to have eroded the function of borders to circumscribe and guarantee citizenship statutes and rights, at the same time increasing the claims about their universality (Balibar 2010). Contemporary social researchers, including anthropologists, often have to come to terms with political borders which have been recognized as weakened, more porous to forces which also shape the state institutions themselves. Political borders also appear as multiplied, with the addition of airports, internal customs and immigration checks, which also function as borders, and some borders that have been outsourced to neighboring states in order to stem migratory flows, despite the popular perception that national borders are natural and relatively fixed. Borders may be displaced, where they seem to oscillate or fluctuate, depending on often-changing personnel, policies or natural features. People often have a clear picture of where the border is or should be placed. But sometimes, these notions are ambiguous or "too lively", like the "unruly currents" of the Drina river, which ratifies a large portion of the border between Bosnia-Herzegovina and Serbia, but keeps changing its course (Brkovic and Jansen, 2019).

Simply put, national and other geopolitical borders are no longer taken for granted in terms of their dimensions, location, and roles, paradoxically making narratives of border management looming more than before (Anderson et al. 2002). As researchers along the internal and external EU borders may attest every day, these longstanding symbols of state power are persistently transfiguring rather than extinguishing. Border peoples and border theorists must deal equally with local and regional claims of autonomy, but also with nation-states sometimes relinquishing, sometimes asserting, their dominant role in demarcating local identities and legitimate residencies. Recent epidemiologic and geopolitical shifts, for example, are giving new resonance to crucial declarations of guardianship of the national interests, bolstering the power of bordered governmental bodies and their territorial margins.

A wide subfield in the literature on borders as political entities approaches the political control of legal and illegal mobility and its relationship with the global labour market. The study of border regimes is mainly inspired by biopolitical theories, and by the concept of governmentality in particular. Based on the idea that "immigrants embody the articulation of borders and boundaries" (Fassin 2011, 215), this type of research finds fertile ground when dealing with policies, practices and representation of contemporary migrations and displaced people. In such cases, the border is mainly interpreted as a device for naming, classifying, and ordering human mobility (Bigo 2007; De Genova 2017), and as the site regulating human flows according to discretional categories of inclusion and exclusion (Pallitto and Heyman 2008; Fassin 2019). The study of migration governance has also led to the analysis of borders as multilayered and multi-located. It confirms that borders are not the same for everyone, nor are they experienced in the same way. According to this approach, borders operate wherever political divides generate distinctions between norms and exceptions, shaping multiple forms of exploitation and segmented assimilation (Ong 2006; Cuttitta 2006). Connected to the functioning of the global market economy, they are agents within assemblages of power that nonetheless reconfigure state territory and authority (Mezzadra and Nielsen 2013). 
In addressing the political actions of borders, these studies shed light on their being part of a differential stratification of risks and (in)securities. This frame certainly shows them as more complex than a line drawn in terms of pure legal abstraction, and provides a valuable complement to much that passed in the past. However, biopolitical readings may also keep offering a markedly structuralist and functionalist understanding of borders, which are chiefly pictured through top-down procedures, with technology and institutions framing if not subjugating individuals and groups in borderlands and elsewhere in body politics. This allowed borrowing from realist politics to treat borders as theoretical abstractions and formal devices, thus limiting the understanding of borders as complex socio-spatial formations. While contemporary studies of the state and its borders would be likely to investigate various sources of power and control beyond the organs of government - through a much wider lens that included civil society, NGOs, and transnational bodies - such studies would still benefit, in our opinion, by including more ideas revolving around the spatial reality of borders, their geographical and historical settings, the varying territorial and relational dynamics influencing their social life, such as those of who cross them.

Furthermore, ethnographic research on borderlands - including many studies dedicated to 'sensitive' border areas of the former Iron Curtain (Paasi 1996; Berdahl 1999; Glaeser 2000; Pelkmans 2006) - show two data points usually neglected by a body of literature that fundamentally analyzes borders as a mode of governance. First, the border works well, at least for the state, where there are fewer perceived exceptions, that is where it creates a naturalized order, a taken-for-granted space regulating flows and blockages, including gaps, gray areas, and the exceptions it creates. Second, border regimes are not politically ubiquitous to the point of embracing the full spectrum of forms of social belonging, distinction and exclusion. Borderscapes themselves are affected by many other ways of making place, that the perspectives mentioned above tend to detect only through limited political categories.

\section{Border as representation and idea}

While much theorizing in 'border studies' before and since the 1990s utilized various theories of the state, governance, citizenship and sovereignty, 'border theory' has come to be known too for its view of borders as social constructions. The second approach that we will outline here is primarily engaged in the study of metaphorical boundaries that join and divide individuals and groups, as persons, cultures and identities, always dealing with the vicissitudes of space, place and liminality. In this approach, pioneered for so many by Anzaldúa (1987), ethnographies are nourished by the complex connections between borders and patterns of social belonging. While political analyses put the border issue at the center of the workings of states and politics, this type of work focuses on bottom-up dynamics and on small-scale locations, looking at the cultural construction of everyday life in local contexts, and at the phenomenology of experience in border settings.

A key theme in this approach to borders is human agency, with a focus on cultural representations, patterns of individual intentionality, incorporated memories of borders, bordering as part of signifying systems, spatial practices which give meaning to the boundaries (see, for example, van Houtum et al. 2005; Cozzi 2009; Stokłosa 2019). Where these studies aim at observing border landscapes, they often privilege material and symbolical traces of 
people's community-building and place-making. They show borders as viewed, negotiated, and reconstructed from below, associated with other elements of the cultural landscape. As a consequence, research shows social zones of varying meanings and sets of linkages, socially produced and reproduced between persons and with the environment. These visions of border shed light on vernacular landscapes (Jackson 1984), and representational spaces filled with imaginaries and everyday practices (Lefebvre 1991). Furthermore, ethnographic research on cultural representations of borders usually adopts phenomenological theorizations of place. The landscape is thus intended as "a medium rather than a container for action", as a space that "does not and cannot exist apart from the events and activities within which it is implicated" (Tilley 1994, 10). Boundaries lose their objective social salience, since space acquires meaning through and is defined by the subject experiencing it. This may be seen, for instance, in recent developments in sensory and aesthetic approaches to studying borders as cognitive or embodied maps (Said 2013; Schimanski 2015).

Among the findings of these anthropological studies is, first, that borders are made and remade in multiple ways by the subjects within the process of occupying and shaping the space. Second, that the local representations cannot be entirely inferred from state delimitations and major identity narratives. Border encounters, local traditions, and varying symbolic resources operate as cultural strategies not only in reproducing and establishing boundaries, but also in challenging institutionalized social differences. A relevant part of this literature has been influenced by and resulted in spatial deconstructivism, often based on the intention to create an epistemological break in the postulated correspondence between sovereignty, society and territory. This theoretical framework is epitomized by proposals to liberate the study of borders from the "territorial trap" (Agnew 1994). It encourages the historicizing of maps, to read them as a medium expressing a social construction of the world. Moreover, it usually offers a postmodernist reading of these, interpreting borders as a technology of power to realize or manifest the ideology they represent (Harley 1989; Cosgrove 2006). From this point of view, this body of research draws near the above-mentioned studies of governmentality, wherein local narratives are often traced as expressions of cultural resistance, social struggle and political creativity, or as independent agencies softening or threatening geopolitical structures and their narcissistic centripetism (van Houtum 2011; Scott et al. 2018; Tyerman 2021).

Centered on narratives and counter-narratives of borders, this approach may tend to move far from an observation of the borderland as a territory. Its political, historical, and geomorphological characteristics are considered to have little truth beyond their internalized presence. ${ }^{4}$ Taken alone, this frame may become insufficient to analyze how borders keep embodying the functioning of modern states, which, as discussed above, stand as the primary institution of power and control requiring political, social and symbolical performances (Salter 2011). Furthermore, the single focus on experienced dimensions might conceal how borders as territory - with their physical environment, structures and institutions - have a generative function of political and social action.

Borderlands are populated and regulated by many barriers and bridges, which are often settled by legal and political definitions of sovereignty and citizenship, as much as by local identifications and social exchanges (Donnan and Wilson 2010). There is no doubt that these interrelations and matches are not mechanical expressions of the sole geography drawn by political structures, nor by other authoritative forces that draw the frontiers of laws, rights and 
social recognition. However, once the mirror of mimesis is shattered, the border keeps revealing the dialectics between its political spatial performances and its cultural meanings. These being-in-the-world experiences interlock with the physicality, materiality, and political realization of border landscapes. Social research on borders, then, still needs to find ways to steady these tensions. Representations of the borderscape will need to be reconstructed as "dialectics at a standstill" (Benjamin 1999, 462), in dialogue with everyday life and charged in its historical complexity.

\section{Rendezvous points: Borderscapes as negotiations of territoriality}

Because of the very role of the border, and because of its considerable contemporary transformations, the two research directions we have sketched so far have both moved towards the study of the border as a process, looking at splintered spatial practices and at ideas in motion. In the same fashion, the problem of redefining territoriality arose in order to respond to the challenge of changes in the global political landscape (Paasi 1998). These goals draw closer to Arjun Appadurai's concept of scape, which involves the idea of cultural flows in movement and under permanent construction, which vary according to the point of view (Appadurai 1994). However, the main drawback with this argument is that these problems and tensions often result in a programmatic de-territorialization of the politics of place. On the one hand, many studies disconnect the new politics of transnational flows and relational spaces from spatially-bounded processes and institutions, for instance by putting an emphasis on society in terms of interactional networks (Amin 2004). On the other hand, most current ethnographic explorations of borders embrace the contested, subjective, and irregular nature of spatiality, by examining boundaries as socially designed artifacts expressed in imaginaries, thus emphasizing the dispersed, formless, placeless, and ultimately borderless nature of cultural fluxes.

The term borderscape emerged within border research "allowing for a study of the border as mobile, perspectival, and relational" (Rajaram and Grundy-Warr 2007, x). Its use often stresses the dynamicity of bordering, oscillating between the ontology of borders and the politics of belonging and recognition. However, also this conceptualization is not without the risk of underestimating the role of territoriality. While interestingly stressing the importance of borders as an environmental ground for social interaction, Rajaram and Grundy-Warr, for example, assume borders are not recognizable in physical locations, and must be read through a biopolitical framework. Border scholars should thus be "not simply concerned with landscapes per se, but with landscapes of power" (ibid., XXVI). Other reflections on borderscapes have sought to encompass the multiple social and spatial imaginaries linked to border place-making. Here mainly intended as a symbolic, discursive construction, the concept offers insight on the imagined inter-textual reality of borders (Strüver 2005). In studies giving to imaginaries an inherent resistance to state demarcations, the borderscape is "an ambivalent space of both power and resistance" (Schimanski 2015, 37), and a concept supporting new counter-hegemonic forms of the political and of the social liberated "from the burden of the 'territorialist imperative' "' (Brambilla 2015, 18). 
Without dismissing the important insights they provided, these proposals have revealed a tendency to reproduce the epistemological separation between border as an effect of political powers and border as zone of social interactions, contingent meanings, and discursive signification. The concept of borderscape may improperly suggest, especially if deprived of its spatial dimension, an innate contrast between the supposed rigidity of territorial sovereignties and the again supposed vitality and otherness of bodies questioning all legal and bureaucratic abstractions. We argue here that a more effective processual approach should not assert their de-territorialized and dispersed nature at the expense of other forms of bordering. On the contrary, the study of borderscapes should stress the fact that cultural flows also move across and are made of territories and material infrastructures, therefore exploring human relations as they intertwine with the structure and materiality of border institutions, as much of the anthropological research has done while drawing connections between the politics and the place-making of borders.

All discursive knowledge, interpretive process and embodied experience also has territorial contexts that foreground as the existential ground of imaginaries, constituent powers, and their spatial effects. Borders are the physical spaces in which these links become more pressing and ethnographically accessible. Not by coincidence, theories about the deterritorialization of fluxes are here more visibly challenged. As interfaces between different states and groups, borders are often fields of dense political, social and cultural negotiations, mixing, and interactions. From this stems the inadequacy of methodologies for border research that reproduce a dichotomy between political and vernacular dimensions of borders. Because of its liminal nature, border-zone institutions and constructs are constantly interactive, being "interstitial arenas" (Donnan and Wilson 2003) where different modes of territoriality are negotiated and performed.

In debating the concept of borderscape, what is proposed here is thus a rapprochement to its territorial dimensions. The term borderscape should not be dissociated from the landscape, embracing its etymological dialectic between space as a - politically informed - thing and its - culturally expressed - representation. This can be a useful strategy also in testing dichotomies between power and resistance, as well as between border as a tool of governmentality defining the edges of the norm, and the lived and dynamic border as a site of struggles and exclusion. In this regard, it is helpful to implement the proposal of a processual geography wherein "flows can create, reproduce, and transform geographic spaces" (Heyman and Campbell 2009, 131). As border landscapes clearly show, relationships between mobility and spatial entities are usually not simply disordered or de-territorialized. The dynamics and disjunction of borders do not simply occur on the global flow of imaginary landscapes, nor in an abstract space of political operations. Connected to social systems made of "concrete interconnections among places" (Friedman 2003, 10), flows rearrange the territories that they cross becoming part of them (Anderson and O'Dowd 1999). On the one hand, flows are differentiated and polarized reproducers, creators and obliterators of organized spaces and of discourses interlocked with them. On the other hand, they are always situated within a "used territory" (Santos 2021) inhabited, enacted, and traversed by historical processes. Both as a political artifact and as experience, borderscapes are the material and conceptual result of multiple "border solidification" (Harbers 2003), made of spaces other than by the projection of acts of imagination of the world (Paasi 1996; Fabietti 2011). Reflections about borderscaping, then, 
aim at inserting processuality directly into the material existence of political borders, correcting the paradox for which the spatial turn in social sciences hesitates in embracing geographical grammars and social theories based on territoriality. As a consequence, borders will not be limited to instruments of sovereign powers, nor to cultural products of textual, ideological and symbolical abstraction. Being something more than the locus of an "invented reality, an appealing truth" (van Houtum 2011, 51), they can be better observed as true and literal political artifacts, shaping and made by shaping spaces.

Structural dynamisms and multiple and contested definitions of otherness cannot be avoided in border ethnographies, these dealing with the "frontier effect" (Donnan and Wilson 2010) which contribute to borderlanders' life. The changeability of border narratives is not, then, a denial of their historical and geographical reality, nor an affirmation of their dematerialization and arbitrariness. Rather, they confirm the material, functional and symbolic presence of borders, thus their ability to forge complex cultural landscapes. Borders could therefore be understood as a central object of social analysis precisely because they are central poles of interaction between the spatial production of society and the social production of space. A border operates both as a dynamic, though organized, political place, and as a dynamic medium through which border experiences are organized, classified and interpreted. As a place, it provides and expresses symbolic and functional markers of inclusion, exclusion or abandonment, which ethnographies observe as well in terms of social organization. As a medium, it comprises the complex conjunction between the varying morphological presence of borders, their bordering, de-bordering, and re-bordering practices, and their imagination.

\section{Contributions to the anthropology of borders in Southeastern Europe}

This special issue brings together ethnographic research in borderlands and anthropological understandings on borders and bordering processes in Southeastern Europe. Many characteristics of this region make it both an interesting ethnographic field for the research on border territories as connected to specific issues of place, identity, and citizenship, and a privileged site for tracing global dynamics in the contemporary political life of borders and borderlands.

Longue-durée and contemporary phenomena in Southeast European terrains generate fascinating as much as crucial opportunities for ethnographic research on borders. Foremost among these opportunities is the proliferation and continuous historical changes that have affected borders, political authority, and the organization of states and social groups in the region. Since the Ottoman Empire, through the Yugoslavian federation and the recent troubled and differentiated paths of European integration, the region experienced a political map of highly variable geography. If measured through the lens of the political categories of the modern nation-state, the history of the region stands out for the repeated large oscillations of the local demos/ethnos binomial. These are associated with shifting political representations and practices of borders, as well as with the complex articulation of social boundaries, both drawing borderscapes with multiple morphologies on different levels. The Southeast European history has been intersecting and continually articulating modern forms of supra-ethnic citizenship, traditional and informal forms of social organization, and administrative orders and 
rules that attempted to draw resources from religious, kinship, and ethnic affiliations. In particular, research on the Balkans has extensively emphasized, and questioned as well, an aggregate of common regional characteristics. These include its predominantly peasant economy, its peripheral inclusion into a series of supranational systems, the multi-ethnicity and religious coexistence of its people. Extensive coverage has been given to structural commonalities stemming from a shared legacy of Byzantine, Ottoman, and socialist eras, as well as by patterns in the post-socialist transition.

Another crosscutting trope is certainly that of being par excellence an area of contested powers. Stemming from different perspectives, concepts such as "penumbral borders" (Paasi and Zimmerbauer 2016), "versatile borders" (Darques 2017), "phantom borders" (von Hirschhausen et al. 2019), and "entangled borders" (Green 2019), highlight the fragmented sedimentation of borderlands, the multiplicity of border regimes, their highly contextual and selective significance, and the cohabitation and overlap of different bordering practices and arenas. The social analysis of Southeast European contexts comes to terms with intricacies and border complexities, with the contested legacy of former socio-political patterns of territoriality, with mismatched interactions between contemporary regional blocs, states, administrations, and local communities. Moreover, as it is known, the local political geography has an equally complex and painful contemporary history, expressed on a map forged by territorial struggles and fueled by old and newer leading powers, international pressures, imperial and national narratives. In few decades, many existing classifications of places and people have been eroded or restructured, others invented, established, or reinforced. A large and growing body of literature thus investigated the dramatic changes of border regimes, as well as the changing role of borders in ideologies and political practices.

The articles collected within this special issue confirm Southeastern Europe as an interesting field of analysis of the impact that new ideological and power configurations have on political borders, on modes and layers of identification, and therefore on the everyday life of borderlanders. These contributions also describe the role of geo-cultural imaginaries penetrating both public and scholarly discourses. As notably argued by Maria Todorova, the study of the Balkans appears marked by an "unhealthy obsession with distinction, difference, with otherness" that also manifests itself through "borders as a preferred object of analysis" (Todorova 2002, 62-63). Thus, the edge of the region is not only the result of historical legacies, nor it is only expressed in complex spatial issues. It is also embedded in mental maps that enshrine its definitions, normative presumptions, and conceptual systems of reference. Rather than accountability of innocent definitions derived from alleged "unmarked categories" (ibid., 82), the study of the region as a "regime of spatiality" (Mishkova 2018) can then better support the study and straighten it out of hegemonic narratives and essentialized geo-imaginaries.

The first article following these pages engages the readers on the relation between borders and spheres of legitimate actions. Robert Hayden has relied on his extensive research activity on the Balkans, brought together by the intent to look at how ideologies and bureaucracies enter the patterns of social life, in proximity with those local perceptions that drove social action in the region (Hayden 2013). Observing the wide variety of authorities and collectivities that define the legitimacy, values, and logics of borderness, Hayden invites us to look at the Southeast European context, and beyond, from this multipolarity of territorial and nonterritorial jurisdictions that affect territories, the politics of borders, citizenship regimes, and 
ethno-national-religious identities. The article then poses one of the central problems in the study of international borders: many border arrangements crosscut and overlap sovereign political borders, offering both opportunities and challenges to ethnographers of borderlands who have to deal with the major narratives of state territory and sovereignty.

As discussed above, territoriality is a shared key element in the examination of the borders, frontiers, and boundaries that delimit and define geopolitical entities, as well as material and human flows. Confirming the importance of this focus, Thomas Wilson's article offers a look at the palpability of the European Union border. The European Union presence, policies, and management of state borders and supranational frontiers are crucial to understanding the lives of several inhabitants of borderlands. The article focuses in particular on the relevance of what recently occurred in Northern Ireland with Brexit, which illustrates the concrete influence that the process of European transnational integration has had on border contexts. Brexit asks us to consider whether similar dynamics affect other areas at the edge of the Union, where claimed regional and national identities overlap with the promise and seeking of EU benefits.

The concept of 'European borderland', here associated to Southeastern Europe, supports the proposal to look at the borders of supranational entities in spatial terms, i.e. with an epistemology that does not necessarily need to distinguish them from how other political borders, such as those of nation-states, are observed. The text thus restates the idea of political borders as territories where state and belongings interact and intersect more vividly (Wilson 2012). The topic of European integration - together with the disaggregation of the former and today's border regimes - also offers lenses that have been little employed to date, which allows approaching the region as a whole case study with its many internal variations. The European dimension of these border regimes raise some conundrums. First, the EU influence is an issue involving the whole region, creating there new inter-regional differences and imbalances. Among the key factors in the contemporary Southeast European border regimes and internal borders, we certainly need to mention the differential progress of the European Union integration and enlargement (Taylor et al. 2013), as well as the growing influence of European policies beyond the EU borders (Lavenex and Schimmelfennig 2009). Historical legacies are then not the only elements to be called into question in understanding the region today, which is, on the contrary, marked by a deep questioning of these legacies. The severe, sudden closure of the former internal boundaries within the Yugoslavian and Soviet federations triggered a long chain of political crises that precisely address borderlands and identity frontiers as a matter of international and geopolitical concerns. As Darques (2017) illustrates, the growing disclosure and erosion of the federal perimeters, formerly under the harsh monopoly of military authorities, is counteracted by the dramatic exacerbation of their previous internal borders. New inter-regional and semi-federal agreements not only led these openings, but are changing the regional geography through infrastructures and facilities built from scratch, supported and financed by the new interests and geopolitical partners.

A second conundrum concerns European multi-level governance, which is undoubtedly one of the main structural factors shaping local state-building projects and public debates. Contrary to widespread assumptions, not only endogenous but also exogenous drives make Southeastern Europe illustrative of both a relevant degree of political and institutional porosity and of the trend to conceive of political borders as strong. While leading programs to boost transnational cooperation and to harmonize border regimes and border-crossing procedures, 
the EU, among other international actors, has a decisive influence also in broadening the distance among variegated types of citizenship, unfolding local tensions and disseminating opaque policies. Circumscribing the region as 'a periphery of Europe' contributes in several senses to understand why "here borders still matter" (Andreev 2004, 382). For instance, the prominence of European governance is exemplified by the regional agenda on ethnic and religious minorities, on refugees and migrant guest-workers, on terrorism and criminal trades. It stands out similarly while researching quasi-state entities or constituent republics, like Kosovo or Bosnia-Herzegovina.

Finally, while confirming the insufficiency of the state framework in understanding regions and local borders, a European perspective allows at the same time to reflect on states and territories without resorting to essentialist assessments about national identity. The ethnographies gathered here authenticate the influence of past and present regional, interregional, intrastate, federal and semi-federal political borders, which are all shaping together with other bounded forms of social organization - regional geography. For many of these border formations and transformations, the European patterns of multi-level governance have a prominent role. The concept of 'European borderland' then serves to illustrate, rather than an indeterminacy of European political boundaries, the co-presence of a complex of ubiquitous and multiple borders. As Balibar has pointed out, these characteristics make the Balkans "rather an epitome and an allegory of Europe" (Balibar 2009, 200). In this sense, current dynamics do not seem to undermine the possibilities of treating the region as a unit. Rather they are creating new political, social, and historical features that will allow investigating the region altogether on many issues, those of borders included.

The third contribution to this special issue is dedicated to an ethnographic exploration of Zrnorsko, a village on the Albanian side of the trilateral border region of Prespa lakes. The research focuses on the interaction between productive activities and spatial practices in this rural landscape. Research on the local social economy thus connects to two terrains on which the anthropological tradition on the region has long been trained: the transformations of peasant societies and the role of regional identities within the processes of place-making and boundary maintenance (Byrnes 1976; Halpern and Kideckel 1983). Both the history of productive activities and the local space-orienting elements offer insight into how place-making processes connect to the social economy and its historical changes. Identity issues and macro-political phenomena thus become approachable as embraced to specific relationships with the environment and its inhabitants. As the introductory anecdotes to this article were intended to suggest, ethnography carried out in border territories pushes the analysis to tilt between space and place. In an attempt to draw connections among the two, the fieldwork team in Zrnorsko adopted two approaches in particular, which stress this tilting as remarkably fruitful. On the one hand, fieldwork activities investigated how the productive history of this borderland intersected with the story of the village and of research participants. On the other hand, they drew an exploration of local spatial practices through a participatory mapping activity.

This work contributes to scholarship that shows the importance of everyday practical and symbolical work in eliciting borders and boundedness (Reeves 2011). Material and symbolic boundaries jointly participate in ecological formations, where border logics appear to be constructed and operated, renamed or dismissed, like fields and streets. At the same time, empirical findings show how broader logics and power relations reverberate in local 
environments and boundaries. Global drivers of power and authority contribute to the drawing of polysemous and polymorphic borders, and the same border technology and standardized procedures deliver different performances according to the subjects and contexts involved. These logics influence imaginaries of both interstitial and core spaces (Carnevale 2018), and as widely postulated (Green 2005; Anderson 2012; Zielonka 2017) - they tend to diversify more between central and marginal spots of the same broad social domain than to circumscribe binary Westphalian political entities. In short, they give borders the capacity to differentiate the ability to live a normal life (Cunningham and Heyman 2004; Dzenoska 2014). As studies of the post-socialist transition confirm (Wolfe 2000), peripheral place-making strategies are far from being beyond the systemic changes in the political economy of states. Nonetheless, in the case of Znorsko and neighboring villages, these changes seem mainly to produce people, areas, and frontiers, not of concern.

The article by Theodoros Kouros shifts the object of investigation beyond the Balkan peninsula. Based on his ethnographic research in Nicosia, Cyprus, he analyses the grassroots boundary-making that regulates the frontiers internal to societies. The article focuses on sidewalks, an urban element implicated in urban crossing regulations and in everyday bottomup bordering codes. This Cypriot cityscape support thoughts of how boundary narratives are constantly fueled with claims and counterclaims, and how informality and transgressions of formal laws might become an integral part of border regulation.

A substantial part of this special issue is dedicated to ethnographies of borderlands touching the issue of identity. The topic has a prominent feature in the social investigation of this region, and it has long been studied as a chief factor in unresolved territorial issues. These articles make several contributions to the question of how dimensions and sentiments of belonging contribute to structuring social, economic, and political relations, driving ethnographic connections between borders and boundary-making. For example, ethnographies of language, music and dances become ways to research the social life of political borders through externalization and internalization of cultural traits. On the one hand, code-switching, language strategies, and dance performances reveal the penetration of nationalistic standings and claimed ownership of regional traditions, set as "obligation to guard the frontier". On the other hand, while internalizing state-sponsored linguistic and folkloric ideologies, research participants show practices renovating the sense and meanings of territoriality, through strategies of "subversive heteroglossia" that preserve and build spaces of cultural intimacy (Hertzfield 1997), or establishing chances for creative use of identity traits.

Rachele Bezzini, Gilles de Rapper, and Ana-Cristina Irian follow ties, traces, and emerging patterns in the imaginaries about Italy in Gjirokaster, southern Albania. Symbolic boundaries, cultural differences, and new proximity through migrations are established on multiple poles - national, ethnic, religious, educational - influencing both the public and domestic spheres, the local infrastructures and souvenir photos. In the following article we are brought to Koshovice, an Albanian village a few meters from the border with Greece and from other small mountain settlements of northern Epirus, like Aghia Marina. While tracing the history of this predominantly Orthodox and Greek-speaking village, the researchers focus on how the memory of micro-local ties among border communities intersects with great historical changes affecting the frontier. Legal and illegal cross-border movements, forms of economic cooperation, the mutual collaboration in organizing religious celebrations, weddings and 
mourning, make the nearby Greek village into "the other half of the village", challenging the rigidity of the border between states.

These ethnographies bring to the forefront the fact that, compared to the relatively fixed territorial boundaries of states, local markers of identification are many and ambiguous (Manos 2010). National identity overlaps with other forms of social orderings and politicized differences, which regulate, blur, and partially relocate the borders. The multilayered nature of Balkan borderlands compels the field activity to deal with mismatched forms of social structuring, institutional configuration, and individual experiences (Theodossopoulos 2003; Kaneff and Heintz 2006; Nitsiakos et al. 2008). Drawing attention to marginal contexts, these articles thus support a less structuralist and formalist use of the notions of marginality and centrality. In the direction of what has been proposed here, they confirm that the mobilization of differences and connections are temporarily aggregated and locally exploited along with different principles and shared legacies, that could easily traverse new and old political borders. Research on borderland communities and border-crossers confirms their daily confrontation with liminal and interstitial spaces, thus debunking nationalist essentialization, culturalist reductionisms, and myths of a territory perennially wounded by inter-ethnic and inter-religious enmity, and nonetheless questioning the contemporary bureaucratization of identities and multicultural relations (Nitsiakos 2010). The fragmentation, which we have highlighted as a dominant feature in the debate on borders in Southeast Europe, is thus actually shown as an excess of relations. Many forms of collective and individual identification can fill and transfigure the public sphere (Verdery 1994), and religious and ethnic boundaries have the power to rephrase consistently national discourses (Pusceddu 2018). Whereas institutional apparatuses impose categories and practices of sharp separation - and political borders attempt to accumulate in one single institution the capacity of ordering, social functions, and symbolic authority - these border landscapes remain instead full of unfinished classifications and contested orders, and keep articulating their marginality and indeterminacy (Green 2005).

The article by Sule Can is inspired by her field experience among Syrian refugees. Dealing with the migrants and people massively forced to displacement, this work makes us go backwards through the process of externalization of European borders, which crosses the Balkans and traverses Turkey to reach the Middle East. This is a key issue in understanding what happens in Southeastern Europe, uncovering the role of international organizations, NGOs and global corporate players in today's border securitization. It also unravels regional policies of migration containment and international requests of controlling and governing frontiers, which results in new technologies and old-fashioned militarized, impermeable, and exclusionary edges (Walters 2002; Zaragoza-Cristiani 2017; del Sarto 2021). Using examples from the Turkish-Syrian border, Can shows that this humanitarian crisis should be approached on different levels, from refugee vulnerability and expectations to local border policies and cultural negotiations, to geopolitical bargains and threatens to open the gates to Europe. While referring to the political responsibilities of border agents and institutions, this article draws on the everyday social practices at the borders and across them. Even bodies come to be mobilized as sites of border policing, showing the many existential implications this experience has in people's lives, the researcher' life included.

The special issue concludes with a piece of research suggestively titled 'Don't tell me I don't exist'. The authors dwell on the performances of Macedoniannes in Bitola, inviting us to 
evaluate the penetration of political discourses in the local sense of belonging, and vice-versa. Together with other contributions to this special issue, the work validates the limited effectiveness of many local state frontiers, and the centrality of praxis in defining local fields of authority. On the one hand, these weakened borders reflect the political status of their states, which oscillates between the crisis of legitimacy and efficacy of the ruling systems, and the authoritarian tendencies of apparatuses in search of empowerment (Bieber 2019). On the other, the research confirms that strong identifications can go hand in hand with the distrust toward the state, leaving place to the social importance of kinship, friendships, as well as to a multitude of local factors differently dealing with the polarization of national discourses and ethnic identities (Malešević 2019). As the last article reminds us, narratives of national belonging remain an inescapable element in the contemporary understanding of Southeastern Europe. New readings of history and cultural heritage, as well as the rediscovery, redefinition or invention of antique national, regional, and supranational roots, are a problematic and necessary object of study of the transformations of many regions of the contemporary world, requiring them to be undertaken seriously as cultural agents of social change. Anthropologists and historians often have a responsibility toward these issues, especially in regions where still burning identity statements also encounter a regional disciplinary tradition predominantly focused on folklore, ethnological collections, and local cultural heritage, often incorporating cultural essentializations, national ideologies, and touristic brandings.

The anthropological research collected within this special issue confirms the heuristic value of the territory as the threshold where the political and geopolitical configuration of powers interacts - even when not converging - with forms of identification and metaphorical negotiations, creating discursive knowledge about the place. First, this approach shows that place-making is made of spatial and temporal processes, of simultaneous displacements and emplacements, of mobility and enclosures which "draw meaning from and give meaning to borders" (Ballinger 2012, 390-391). Research on borderscapes confirms that "the inverse of landed, bounded cultural phenomena is thus not just formless flux but the continual creation of geographic formations" (Heyman and Campbell 2009, 137). Spaces offer a valuable point of observation of the dynamics of border identity, as responding to complex political balances and different place-making strategies. These shape new permeabilities and new divides, dialoguing with context-grounded material and symbolic concerns. Second, this approach shows that there is a concrete space where institutional entities aim to provide social order, meeting and paralleling many other internal and external boundaries. Border landscape is certainly not the site exclusively configured by sovereign powers, and therefore society does not correspond to states, nor identities to nations. In the same breath, the existence of political borders keeps contributing to the making of place in people's everyday lives, pushing the meaningfulness of boundaries even underneath the lines designated and claimed by political powers.

The focus on negotiations of territoriality lays a valuable groundwork for ethnographic research in Southeastern Europe in particular. The studies reviewed here indicate that local public spheres are increasingly marked by attempts to re-use available cultural traits to boost identity claims and legitimize new political polarizations. Like every imagined community, these narratives have an impact far beyond imagination. The anthropology of borders in Southeastern Europe must reckon with renewed complexities and emerging asymmetries, new 
border regimes and social boundaries, and the potential triggers to build new bridges and fruitful border-crossings. It is one more reason why social research should engage in looking at how the essentialization of borders and mobilization of border agencies represent sociocultural practices located in the field, and loaded to some extent with functions, symbolic meanings, and influence.

\section{Acknowledgements}

The majority of the articles collected in this issue of the Anthropology of East Europe Review resulted from the theoretical dialogues and ethnographic research initiated within various meetings of the Konitsa Summer School in the Anthropology, Ethnography and Comparative Folklore of the Balkans. Many of these took their preliminary form as team-based research reports resulting from the short intensive fieldwork projects the participants carried out in locations situated between Albania, Greece, and the Republic of Northern Macedonia. The Konitsa Summer School has been organized by the Border Crossings Network (BCN) since 2006, in collaboration with the Department of History and Archaeology of the University of Ioannina and the Municipality of Konitsa, Epirus. In these years, it offered a theoretical, methodological, and empirical training program in socio-cultural anthropology of Southeastern Europe, fueling this regional field of research with a precious body of fieldwork-based documentation and analyses. At the same time, the School provided a space for social researchers and local experts to advance dialogue on the current political, economic, and environmental issues in Balkan border areas. Davide Carnevale took part in the 2018 Summer School, while Thomas M. Wilson delivered a keynote address at the 2017 Summer School.

Our special thanks thus go to the researchers of the Border Crossings Network, and to the organizers, the academic board, and all the participants of the Summer Schools in Konitsa. We offer particular thanks to Vassilis Nitsiakos and Ioannis Manos for their leadership and support in the Summer Schools which we attended. As editors of this special issue of AEER, we also thank all contributors and reviewers for their work and availability. Thanks are also due to Amanda Krzyworzeka, Emily Channel-Justice, and Indiana University's Scholarworks, for their careful assistance throughout the editorial process. 


\section{Notes}

1 This article introduces the Special Issue "Place-making and Politics of Borderscapes. Contributions to the Anthropology of Borders in Southeastern Europe", co-edited by the authors for Anthropology of East Europe Review, n. 37(1), 2021.

2 In the local dialect, the adjective is also used to mean 'deformed', 'bizarre', 'indecent'.

3 The brief list of references provided is obviously neither exhaustive nor sufficient to account for the variability of approaches to the border as a political object and as a cultural idea. We do not presume to provide such a grand synthesis, not even for the English language literature to which the references are limited. Rather, references are offered as examples of the main trends and trajectories of the latest years.

${ }^{4}$ We can here draw further theoretical parallels with geographical research, mentioning the post-representational rehabilitation of cartography as a polyphonic performance and as a storytelling device (Pickles 2004; Caquard and Cartwright 2014).

\section{References}

Agnew, John. 1994. "The Territorial Trap: The Geographical Assumptions of International Relations Theory." Review of International Political Economy 1, no. 1: 53-80.

Amin, Ash. 2004. "Regions Unbound: Towards a New Politics of Place." Geografiska Annaler 86, no.1: 33-44.

Andersen, Dorte Jagetic, Martin Klatt, and Marie Sandberg, eds. 2012. The Border Multiple: The Practicing of Borders between Public Policy and Everyday Life in a Re-scaling Europe. Aldergrove, UK: Ashgate.

Anderson, James, and Liam O'Dowd. 1999. "Borders, Border Regions and Territoriality: Contradictory Meanings, Changing Significance.” Regional Studies 33, no. 7: 593-604.

Anderson, James, Liam O'Dowd and Thomas M. Wilson. 2002. "Introduction: Why Study Borders Now?" Regional and Federal Studies 12, no. 4: 1-12.

Anderson, James. 2012. "Borders in the New Imperialism." In A Companion to Border Studies, edited by Thomas M. Wilson and Hastings Donnan, 137-157. London: Wiley Blackwell.

Andreev, Svetlozar. 2004. "The border in Southeast Europe: democratic legitimacy and security issues in an enlarging European Union." Southeast European and Black Sea Studies 4, no. 3: 379-398.

Anzaldúa, Gloria. 1987. Borderlands/la Frontera: The New Mestiza. San Francisco, CA: Aunt Lute Books.

Appadurai, Arjun. 1994. "Disjuncture and Difference in the Global Economy." In Colonial Discourse and Postcolonial Theory, edited by Patrick Williams and Laura Chrisman, 392403. New York: Columbia UP.

Balibar, Étienne. 2009. "Europe as Borderland." Environment and Planning D: Society and Space 27, no. 2: 190-215.

Balibar, Étienne. 2010. "At the Borders of Citizenship: A Democracy in Translation?" European Journal of Social Theory 13, no. 3: 315-322. 
Ballinger, Pamela. 2012. "Borders and the Rhythms of Displacement, Emplacement and Mobility." In The Blackwell Companion to Border Studies, edited by Thomas M. Wilson and Hastings Donnan, 389-404. Malden, MA: Wiley Blackwell.

Benjamin, Walter. 1999 [1982]. Arcades Project. Cambridge, MA: Harvard UP.

Berdahl, Daphne. 1999. Where the World Ended: Re-unification and Identity in the German Borderland. Berkeley, CA: University of California Press.

Bieber, Florian. 2019. The Rise of Authoritarianism in the Western Balkans. Basingstoke, UK: Palgrave Macmillan.

Bigo, Didier. 2007. "Detention of Foreigners, States of Exception, and the Social Practices of Control of the Banopticon." In Borderscapes: Hidden Geographies and Politics at Territory's Edge, edited by Prem Kumar Rajaram and Carl Grundy-Warr, 3-34, Minneapolis: University of Minnesota Press.

Brambilla, Chiara. 2015. "Exploring the Critical Potential of the Borderscapes Concept." Geopolitics 20, no. 1: 14-34.

Brkovic, Čarna, and Stef Jansen. 2019. "A Lively Border: Bosnia and Herzegovina and Serbia on the Shifting Banks of the Drina." In Everyday life in the Balkans. edited by David W. Montgomery, 230-238. Bloomington: Indiana UP.

Brown, Wendy. 2010. Walled States, Waning Sovereignty. New York: Zone Books.

Bucken-Knapp, Gregg, and Michael Schack, eds. 2001. Borders Matter: Transboundary Regions in Contemporary Europe. Aabenraa, DK: IFG.

Byrnes, Robert Francis, ed. 1976. Communal Families in the Balkans: The Zadruga. Essays by Philip E. Mosely and Essays in His Honor. Notre Dame, IN: Notre Dame UP.

Cabot, Heath. 2014. On the Doorstep of Europe: Asylum and Citizenship in Greece. Philadelphia: University of Pennsylvania Press.

Caquard, Sébastien, and William Cartwright. 2014. "Narrative Cartography: From Mapping Stories to the Narrative of Maps and Mapping." The Cartographic Journal 51, no. 2: 101-106.

Carnevale, Davide N. 2018. "Criminal Humanitarianism. A Visual Exploration of Criminal Legitimisation, Between Alternative Moralities and the Political Vacuum." Interdisciplinary Political Studies 4, no. 2: 79-125.

Cosgrove, Denis E. 2006. Geographical Imagination and the Authority of Images - Hettner Lecture 2005. Munich: Franz Steiner Verlag.

Cozzi, Donatella. 2009. "The Inner Frontier. Borders, Narratives, and Cultural intimacy in Topolò /Topolove", Traditiones ZRC SAZU 38, no. 2: 151-164.

Cunningham, Hilary, and Josiah Heyman. 2004. "Introduction: Mobilities and Enclosures at Borders." Identities: Global Studies in Culture and Power 11, no. 3: 289-302.

Cunningham, Hilary. 2020. "Necrotone: Death-Dealing Volumetrics at the US-Mexico." In Voluminous States: Sovereignty, Materiality, and the Territorial Imagination, edited by Franck Billé, 131-145. Durham, NC: Duke UP.

Cuttitta, Paolo. 2006. "Points and Lines. A Topography of Borders in the Global Space." Ephemera 6, no. 1:27-39.

Darques, Regis. 2017. Mapping Versatile Boundaries. Understanding the Balkans. Cham,

$\mathrm{CH}$ : Springer. 
De Genova, Nicholas, ed. 2017. The Borders of "Europe": Autonomy of Migration, Tactics of Bordering. Durham, NC: Duke UP.

Del Sarto, Raffaella. 2021. Borderlands: Europe and the Mediterranean Middle East.

Oxford: Oxford UP.

Donnan, Hastings, and Thomas M. Wilson. 1999. Borders. Frontiers of identity, Nation and State. Oxford and New York: Berg Routledge.

Donnan, Hastings, and Thomas M. Wilson. 2003. "Territoriality, Anthropology, and the Interstitial: Subversion and Support in European Borderlands.” Focaal: European Journal of Anthropology 41: 9-20,

Donnan, Hastings, and Thomas M. Wilson. 2010. "Ethnography, Security and the 'Frontier Effect' in Borderlands." In Borderlands: Ethnography, Security and Frontiers, edited by Hastings Donnan and Thomas M. Wilson, 1-20. Lanham, MD: University Press of America.

Dzenovska, Dace. 2014. "Bordering Encounters, Sociality and Distribution of the Ability to Live a 'Normal Life'." Social Anthropology 22, no. 3, 271-287.

Fabietti, Ugo. 2011 [1997]. Ethnography at the Frontier: Space, Memory and Society in Southern Balochistan. New York: Peter Lang.

Fassin, Didier. 2011. "Policing Borders, Producing Boundaries. The Governmentality of Immigration in Dark Times." Annual Review of Anthropology 40: 213-226.

Fassin, Didier. 2019. Deepening Divides: How Territorial Borders and Social Boundaries Delineate Our World Responsibility. London: Pluto Press.

Friedman, Jonathan, ed. 2003. Globalization, the State, and Violence. Walnut Creek, CA: AltaMira Press.

Glaeser, Andreas. 2000. Divided in Unity: Identity, Germany and the Berlin Police. Chicago: Chicago UP.

Green, Sarah F. 2005. Notes from the Balkans: Locating Marginality and Ambiguity on the Greek-Albanian Border. Princeton, NJ: Princeton UP.

Green, Sarah F. 2019. "Entangled Borders.” Archivio antropologico mediterraneo 21, no. 2: 11-24.

Halpern, Joel Martin, and David A. Kideckel. 1983. “Anthropology of Eastern Europe." Annual Review of Anthropology 12, no. 1: 377-402.

Harbers, Arjan. 2003. "Borderscapes. The Influence of National Borders on Spatial Planning." In Euroscapes - Forum 2003, edited by Robert Broesi, Pieter Jannink, Wouter Veldhuis, Nio Ivan, 143-166. Amsterdam: MUST AetA.

Harley, Brian. 1989. "Deconstructing the Map." Cartographica: The International Journal for Geographic Information and Geovisualization 26, no. 2, 1-20.

Hayden, Robert M. 2013, From Yugoslavia to the Western Balkans: Studies of a European Disunion, 1991-2011. Leiden: Brill

Herzfeld, Michael. 1997. Cultural Intimacy. Social Poetics in the Nation-State. New York: Routledge.

Heyman, Josiah. 2017. "Contributions of U.S.-Mexico Border Studies to Social Science Theory." In The U.S.-Mexico Transborder Region: Cultural Dynamics and Historical Interactions, 44-64, edited by Carlos Vélez-Ibáñez and Josiah Heyman. Tucson: University of Arizona Press. 
Heyman, Josiah, and Howard Campbell. 2009. "The Anthropology of Global Flows: A critical reading of Appadurai's 'Disjuncture and Difference in the Global Cultural Economy'." Anthropological Theory 9, no. 2, 131-148.

Israel, Tamir. 2020. Facial Recognition at a Crossroads: Transformation at our Borders and Beyond. Ottawa, CIPPIC.

Jackson, John Brinckerhoff. 1984. Discovering the Vernacular Landscape, New Haven, CT: Yale UP.

Kaneff, Deema, and Monica Heintz, eds. 2006. "Bessarabian Borderlands: One Region, Two States, Multiple Ethnicities.” Anthropology of East Europe Review 24, no. 1.

Lavenex, Sandra, and Frank Schimmelfennig. 2009. "EU Rules beyond EU Borders: Theorizing External Governance in European Politics." Journal of European Public Policy 16, no. 6: 791-812.

Lefebvre, Henri. 1991 [1974]. The Production of Space. Oxford-Cambridge: Blackwell.

Malešević, Siniša. 2019. Grounded Nationalisms: A Sociological Analysis. Cambridge: Cambridge UP.

Manos, Ioannis, 2010. "Fieldwork at the Border: Ethnographic Engagements in South-Eastern Europe." In Borderlands: Ethnographic Approaches to Security, Power and Identity, edited by Hastings Donnan and Thomas M. Wilson, 109-124. Lanham, MD: University Press of America.

Mezzadra, Sandro, and Brett Neilson. 2013. Border as Method, or, the Multiplication of Labor. Durham, NC: Duke UP.

Mishkova, Diana. 2018. Beyond Balkanism: The Scholarly Politics of Region Making. London: Routledge.

Nitsiakos, Vassilis, Ioannis Manos, Georgios Agelopoulos, Aliki Angelidou, Vassilis Dalkavoukis, and Vassiliki Kravva, eds. 2008. Ethnographic Research in Border Areas. First annual of the Konitsa Summer School. Berlin: LIT Verlag - Balkan Border Crossings.

Nitsiakos, Vassilis 2010. On the Border: Transborder Mobility, Ethnic Groups and Boundaries along the Albanian-Greek Frontier. Berlin: LIT.

Ong, Aihwa. 2006. Flexible Citizenship: the Cultural Logics of Transnationality. Durham, NC: Duke UP.

Paasi, Anssi. 1996. Territories, Boundaries and Consciousness: The Changing Geographies of the Finnish-Russian Border. New York: Wiley.

Paasi, Anssi. 1998. "Boundaries as Social Processes: Territoriality in the World of Flows." Geopolitics 3, no. 1: 69-88.

Paasi, Anssi, and Kaj Zimmerbauer. 2016. "Penumbral Borders and Planning Paradoxes: Relational Thinking and the Question of Borders in Spatial Planning." Environment and Planning A: Economy and Space 48: 75-93.

Paasi, Anssi, Eeva-Kaisa Prokkola, Jarkko Saarinen, and Kaj Zimmerbauer, eds. 2019. Borderless Worlds for Whom? Ethics, Moralities and Mobilities. Abingdon, UK: Routledge.

Pallitto, Robert, and Josiah Heyman. 2008. "Theorizing Cross-Border Mobility: Surveillance, Security and Identity." Surveillance and Society 5, no 3: 315-333.

Pelkmans, Mathijs. 2006. Defending the Border: Identity, Religion, and Modernity in the Republic of Georgia. Ithaca, NY: Cornell UP. 
Pickles, John. 2004. A History of Spaces: Cartographic Reason, Mapping and the Geo-Coded World. London: Routledge.

Pusceddu, Antonio Maria. 2018. "Dealing with Boundaries. Muslim Pilgrimages and Political Economy on the Southern Albanian Frontier." In Muslim Pilgrimage in Europe, edited by Ingvild Flaskerud and Richard Natvig, 140-156. London: Routledge.

Rajaram, Prem Kumar, and Carl Grundy-Warr, eds. 2007. Borderscapes: Hidden Geographies and Politics at Territory's Edge. Minneapolis: University of Minnesota Press.

Reeves, Madeline. 2011. "Fixing the Border: On the Affective Life of the State in Southern Kyrgyzstan”. Environment and Planning D: Society and Space 29, no. 5: 905-923.

Said, Noha Gamal. 2013. "Cairo Behind the Gates: Studying the Sensory Configuration of AlRehab City." Ambiances Architectures Urbanités 252.

Salter, Mark. 2011. "Places Everyone! Studying the Performativity of the Border." Political Geography 30, no. 2: $66-67$.

Santos, Milton. 2021 [1996]. The Nature of Space. Durham, NC: Duke UP.

Schimanski, Johan. 2015. "Border Aesthetics and Cultural Distancing in the NorwegianRussian Borderscape”. Geopolitics 20, no.1: 35-55.

Scott, James W., Chiara Brambilla, Filippo Celata, Raffaella Coletti, Hans-Joachim Bürkner, Xavier Ferrer-Gallardo, and Lorenzo Gabrielli. 2018. "Between Crises and Borders: Interventions on Mediterranean Neighbourhood and the Salience of Spatial Imaginaries." Political Geography 63: 174-184.

Stokłosa, Katarzyna, ed. 2019. Borders and Memories: Conflicts and Co-operation in European Border Regions. Münster: Lit Verlag.

Struver, Anke. 2005. Stories of the Boring Border: The Dutch German Borderscape in People's Minds. Munster: Lit.

Taylor, Andrew, Andrew Geddes, and Charles Lees. 2013. The European Union and SouthEast Europe: The Dynamics of Europeanisation and Multi-Level Governance. London: Routledge.

Theodossopoulos, Dimitrios, ed. 2003. "Degrading Others and Honouring Ourselves: Ethnic Stereotypes as Categories and as Explanations". Journal of Mediterranean Studies 13, no. 2.

Tilley, Christopher. 1994. A Phenomenology of Landscape: Places, Paths and Monuments. Oxford: Berg.

Todorova, Maria. 2002. "The Balkans as Category of Analysis: Borders, Space, Time". In Annäherungen an eine europäische Geschichtsschreibung, edited by Gerald Stourzh, Barbara Haider, Ulrike Harmat, 57-83. Wien: ÖAW.

Tsoni, Ioanna W., and Anja K. Franck. 2019. "Writings on the Wall: Textual Traces of Transit in the Aegean Borderscape." Borders in Globalization Review 1, no.1: 7-21.

Tyerman, Thom. 2021. Everyday Border Struggles: Segregation and Solidarity in the UK and Calais. Abingdon, UK: Routledge.

von Hirschhausen, Béatrice, Hannes Grandits, Claudia Kraft, Dietmar Müller, and Thomas Serrier. 2019. "Phantom Borders in Eastern Europe: A New Concept for Regional Research". Slavic Review 78, no. 2: 368-389.

van Houtum, Henk, Olivier Thomas Kramsch, and Wolfgang Zierhofer, eds. 2005. B/ordering Space. Aldershot, UK: Ashgate. 
van Houtum, Henk. 2011. "The Mask of the Border". The Ashgate Research Companion to Border Studies, edited by Doris Wastl-Walter, 49-61. London: Routledge.

Verdery, Katherine. 1994. "Ethnicity, Nationalism, and State-making. Ethnic Groups and Boundaries, Past and Future". In The Anthropology of Ethnicity. Beyond 'Ethnic groups and Boundaries', edited by Hans Vermeulen and Cora Govers, 33-58. Amsterdam: Het Spinhuis.

Walters, William. 2002. "Mapping Schengenland: Denaturalizing the Border." Environment and Planning D: Society and Space 20, no. 5: 561-80.

Wilson, Thomas M. and Hastings Donnan, eds. 1998. Border identities: nation and state at international frontiers. Cambridge: Cambridge UP.

Wilson, Thomas M. and Hastings Donnan, eds. 2012. A Companion to Border Studies. London: Wiley Blackwell.

Wilson, Thomas M. 2012. "Revisiting the Anthropology of Policy and Borders in Europe". In The Border Multiple: The Practicing of Borders between Public Policy and Everyday Life in a Re-scaling Europe, edited by Klatt Martin, Marie Sandberg, and Dorte Andersen. 7796. Farnham, UK: Ashgate.

Wolfe, Thomas C. 2000. "Cultures and Communities in the Anthropology of Eastern Europe and the former Soviet Union". Annual Review of Anthropology 29: 195-21.

Zaragoza Cristiani, Jonathan. 2017. "Containing the Refugee Crisis: How the EU Turned the Balkans and Turkey into an EU Borderland". The International Spectator 52, no. 4: 59-75.

Zielonka, Jan. 2017. "The EU and the European Neighbourhood Policy." In The Routledge Handbook on the European Neighbourhood Policy, edited by Tobias Schumacher, Andreas Marchetti and Thomas Demmelhuber, 142-152. Basingstoke, UK: Taylor \& Francis. 